\title{
Taxonomic note on the genus Metapolypodium (Polypodiaceae)
}

\section{Таксономическая заметка о роде Metapolypodium (Polypodiaceae)}

\author{
A.P. Shalimov ${ }^{1}$, J. Mazumdar ${ }^{2}$ \\ А.П. Шалимов ${ }^{1}$, Дж. Мазумдар ${ }^{2}$ \\ ${ }^{1}$ South-Siberian Botanical Garden, Altai State University, Lenina st., 61, Barnaul, 656049, Russia. E-mail: man_biol@mail.ru \\ ${ }^{1}$ Южно-Сибирский ботанический сад, Алтайский государственный университет, Ленина, 61, Барнаул, 656049, Россия \\ ${ }^{2}$ Department of Biological Sciences, Burdwan Town School, Burdwan-71301, West Bengal, India \\ ${ }^{2}$ Факультет биологических наук, Бурдванская городская школа, Бурдван-71301, Западная Бенгалия, Индия \\ E-mail: jaideepmazumdar10@gmail.com
}

Key words: Asia, Metapolypodium, Metapolypodium manmeiense, Metapolypodium microrhizoma, new combination, Polypodiaceae, Polypodium fieldingianum.

Ключевые слова: Азия, Metapolypodium, Metapolypodium manmeiense, Metapolypodium microrhizoma, новая комбинация, Polypodiaceae, Polypodium fieldingianum.

Summary. Taxonomic status of Metapolypodium (Polypodiaceae) is discussed which is accepted as a distinct genus comprising two species $-M$. manmeiense (Christ) Ching and M. fieldingianum (Kunze ex Mett.) Shalimov et Mazumdar, comb. nov.

Аннотация: Обсужден таксономический статус Metapolypodium (Polypodiaceae), который принят в качестве самостоятельного рода, включающего два вида - M. manmeiense (Christ) Ching и M. fieldingianum (Kunze ex Mett.) Shalimov et Mazumdar, comb. nov.

In its current sense Metapolypodium Ching is a small genus with two species confined to Asian tropics (Zhang et al., 2013). Ching (1978b) separated Metapolypodium from Polypodium L. s. 1. He transferred Polypodium manmeiense Christ to Metaplypodium and designated it as M. manmeiense (Christ) Ching, as generic type, and simultaneously described $M$. kingpingense Ching et W.M. Chu which is usually treated conspecific with M. manmeiense (e. g., Lu, 2000; Lu, Li, 2006; Zhang et al., 2013). Yang et al. (2010) emphasized that Polypodium microrhizoma C.B. Clarke ex Hook. et Baker shares a set of characters with Metapolypodium and should be better places in this genus; they made a combination $M$. microrhizoma (C.B. Clarke ex Hook. et Baker) S.G. Lu et L.H. Yang.

Both species are either placed in Metapolypodium (Ching, 1978a, b; Lu, Li, 2006; Yang et al., 2010; Zhang et al., 2013) or in Goniophlebium (Blume) C. Presl s. 1. (Christenhusz, Chase, 2014; Christenhusz et al., 2011; Kreier et al., 2008; Rödl-Linder, 1990) or in Polypodioides Ching (Fraser-Jenkins et al., 2015).

Metapolypodium manmeiense and M. microrhizoma are distinguishable from all other goniophleboid ferns in having free or partly free veins, similar with free veined Polypodium as noted by Christensen (1931) and Ching (1978b). In Polypodiodes, Polypodiastrum Ching and Goniophlebium veins form areoles along costae are with free vein ending towards margins. Majority of the species of goniophleboid ferns has fugacious soral paraphyses. Polypodiodes formosana (Baker) Ching and Polypodiodes niponica (Mett.) Ching lack for scaly soral paraphyses like M. manmeiense and $M$. microrhizoma, but are distinguishable by prominent costal areoles, hairy lamina, etc. (RödlLinder, 1990). 
Spore morphology is very useful to delimit Metapolypodium from Goniophlebium and Polypodiastrum. Spores of M. manmeiense and $M$. microrhizoma are reniform, with verrucate exospore and smooth perispore, similar to Polypodiodes. In contrast, spores of Goniophlebium and Polypodiastrum show prominent perisporial ridges or crests (Shalimov et al., 2013). Polypodiodes lachnopus (Wall. ex Hook.) Ching (Shalimov et al., 2013) and Polypodiodes hendersonii (Bedd.) FraserJenk. (Chang et al., 2006) also show perisporial crests, but are distinguishable by rhizome scale with filiform apices, scaly paraphyses in sori, prominent costal areoles, etc. (Rödl-Linder, 1990).

Molecular data (Kreier et al., 2008; Lu, Li, 2006) revealed Metapolypodium as well supported subclade in "goniophleboid clade", and venation pattern, spore morphology, soral paraphyses, etc. support Metaplypodium as a good genus having close relationship with Polypodiodes.

Molecular data (Kreier et al., 2008; Lu, $\mathrm{Li}$, 2006) also showed close relationship of M. microrhizoma with $M$. manmeiense as earlier was indicated morphologically by Christensen (1931). These two species share similar verrucate spores, clathrate rhizome scales with acuminate apices, lamina without acicular hairs, free venations, absence of scaly paraphyses in sori, etc. that justify their placement in one genus.

Nomenclature of $M$. microrhizoma needs revision. The name Polypodium microrhizoma was proposed by Clarke and validated by Hooker and Baker (1874). However, Clarke (1880) himself noted that an earlier name, $P$. fieldingianum Kunze ex Mett., published by Mettenius (1857), has priority over $P$. microrhizoma. But type material which he studied was incomplete (without rhizomes) and he did not proceed further study. Similarly, Rödl-Linder (1990) treated $P$. fieldingianum conspecific with $M$. microrhizoma but she was unable to find the type of $P$. fieldingianum and no nomenclature change was attempted. Finally, Fraser-Jenkins et al. (2015) restored the priority of $P$. fieldingianum over $P$. microrhizoma but placed the former in Polypodioides. As discussed above, its correct position is in Metapolypodium and a new combination is proposed here.

Metapolypodium fieldingianum (Kunze ex Mett.) Shalimov et Mazumdar, comb. nov. Polypodium fieldingianum Kunze ex Mett., 1857, Farngatt. 1 : 75. - Goniophlebium fieldingianum (Kunze ex Mett.) T. Moore, 1862, Index Fil. : 389. Polypodioides fieldingiana (Kunze ex Mett.) FraserJenk., Kandel et Pariyar, 2015, Ferns and Fern-allies of Nepal $1: 42$.

Lectotype (selected by Fraser-Jenkins et al., 2015): "Himalaya [country unknown], Fielding, Hofmeister" (B, image!).

\section{Acknowledgements}

We sincerely thank Prof. B. Zimmer for kindly tracing the specimen and sending the image on behalf of Botanical Garden and Botanical Museum in Berlin-Dahlem, Berlin. Research was supported by the RNF № 14-14-00472 and Ministry of Education and Science of the Russian Federation in within the base portion of the state task in the field of scientific research Altai State University (project code 316).

\section{LITERATURE}

Chang Y.-F., Wang R.-X., Lu S.-G. Morphological and anatomical studies of subfamily Polypodioideae (Polypodiaceae) // Acta Botanica Yunnanica, 2006. - Vol. 28, No. 6 - P. 587-592.

Ching R.-C. The Chinese fern families and genera: systematic arrangement and historical origin // Acta Phytotaxonomica Sinica, 1978a. - Vol. 16, No. 3. - P. 1-19.

Ching R.-C. The Chinese fern families and genera: systematic arrangement and historical origin (cont.) // Acta Phytotaxonomica Sinica, 1978b. - Vol. 16, No. 4. - P. 16-37.

Christenhusz M.J.M., Chase M.W. Trends and concepts in fern classification // Annals of Botany, 2014 - Vol. 113. - P. 571-594. [doi:10.1093/aob/mct299]

Christenhusz M.J.M., Zhang X.-Ch., Schneider H. A linear sequence of extant families and genera of lycophytes and ferns // Phytotaxa, 2011. - Vol. 19. - P. 7-54.

Christensen C. Asiatic pteridophyta collected by Joseph F. Rock, 1920-1924 // Contributions from the United States National Herbarium, 1931. - Vol. 26. - P. 259-337.

Clarke C.B. A review of the ferns of northern India // Transactions of the Linnean Society of London, Ser. 2, Botany, 1880. - Vol. 1. - P. 425-619.

Fraser-Jenkins C.R., Kandel D.R., Pariyar S. Ferns and Fern-allies of Nepal. Vol. 1. - Kathmandu: National Herbarium and Plant Laboratories, Department of Plant Resources, Ministry of Forests and Soil Conservation, 2015. - 508 p. 
Hooker W.J., Baker, J.G. Synopsis filicum. Ed. 2. - London: Hardwicke, 1874. - 559 p.

Kreier H.P., Zhang X.C., Muth H., Schneider H. The microsoroid ferns: Inferring the relationships of a highly diverse lineage of Paleotropical epiphytic ferns (Polypodiaceae, Polypodiopsida) // Molecular Phylogenetics and Evolution, 2008. - Vol. 48, No. 3. - P. 1155-1167. [doi:10.1016/j.ympev.2008.05.001]

Lu S.-G. Polypodioideae // Flora Reipublicae Popularis Sinicae. Vol. 6, № 2, Pteridophytes / Ed. by Lin Y.X. Beijing: Science Press, 2000. - P. 12-13.

Lu S.-G., Li C.-X. Phylogenetic position of the monotypic genus Metapolypodium Ching endemic to Asia: evidence from chloroplast DNA sequences of $r b c L$ gene and $r p s 4$-trnS region // Acta Phytotaxonomica Sinica, 2006. - Vol. 44, No. 5. - P. 494-502.

Mettenius G.H. Über einige Farngattungen. - Vol. 1, Polypodium. - Göttingen: H. L. Brönner, 1857. - 514 S. [http://gallica.bnf.fr/ark:/12148/bpt6k969880]

Röde-Linder G. A monograph of the fern genus Goniophlebium (Polypodiaceae) // Blumea, 1990. - Vol. 34. - P. 277-423.

Shalimov A.P., Shmakov A.I., Rodionov A.V. Morphology of spores of some representatives of family Polypodiaceae from east, south east and south Asia // Turczaninowia, 2013. - Vol. 16, No. 2. - P. 110-120 [in Russian].

Yang L.H., Shao W., Lu S.G. A new combination species of the genus Metapolypodium Ching (Polypodiaceae) in China // Journal of Wuhan Botanical Research, 2010. - Vol. 28, No. 4. - P. 507-509.

Zhang X.C., Lu S.G., Lin Y.X., Qi X.P., Moore S., Xing F.W., Wang F.G., Hovenkamp P.H., Gilbert M.G., Nooteboom H.P., Parris B.S., Haufler C., Kato M., Smith A.R. Polypodiaceae // Flora of China. Vol. 2-3, (Pteridophytes) / Ed. by Z. Y. Wu, P. H. Raven, D. Y. Hong. - Beijing: Science Press; St. Louis: Missouri Botanical Garden Press, 2013. - P. 758-850. 